\title{
Axial Coordination of Imidazoles by meso-Nitro Substituted Zn-Octaethylporphyrins
}

\author{
Galina M. Mamardashvili, Olga M. Kulikova, Natalya V. Chizhova, \\ Nugzar Zh. Mamardashvili, ${ }^{@}$ and Oscar I. Koifman
}

Dedicated to Academician A. I. Konovalov on the occasion of his $80^{\text {th }}$ birthday

G. A. Krestov Institute of Solution Chemistry of Russian Academy of Sciences, 153045 Ivanovo, Russia

@Corresponding author E-mail: ngm@isc-ras.ru

The study of complex formation between mono-, di-, tri- and tetranitro meso-substituted Zn-octaethylporphyrins with imidazole and 1-methylimidazole by UV-Vis titration method showed that binding ability of the Zn-porphyrins towards investigated $N$-containing small organic molecules depends on the number of electron-withdrawing nitro-groups in the macrocycle. Taking into account the fact that binding is accompanied by a clear and easily identifiable response in the $U V$-Vis spectra of the reaction mixture, tri- and tetranitro substituted Zn-porphyrins could be considered as molecular optical sensing devices for small heterocyclic substrates.

Keywords: Zn-octaethylporphyrin, meso-nitro substituted porphyrins, electron withdrawing groups, axial coordination, binding ability, stability constant.

\section{Аксиальная координация имидазолов мезо-нитрозамещёнными Zn-октаэтилпорфиринами}

Г. М. Мамардашвили, О. М. Куликова, Н. В. Чижова, Н. Ж. Мамардашвили, ${ }^{\circledR}$ О. И. Койфмман

Посвящается академику РАН А. И. Коновалову по случаю его 80-летнего юбилея

Институт химии растворов РАН им. Г. А. Крестова, 153045 Иваново, Россия

@E-mail:ngm@isc-ras.ru

Исследованием комплексообразования моно-, ди-, три- и тетра мезо-замещтенных Zn-октаэтилпорфиринов с имидазолом и 1-метилимидазолом методом спектрофотометрического титрования показано, что комплексообразующая способность перечисленных Zn-порфиринов по отношению к исследованным $N$-содержащим мальм органическим молекулам определяется числом электроноакцепторных нитро-групп в макроцикле. Принимая во внимание то обстоятельство, что комплексообразование сопровождается четким и легко идентифицируемым откликом в спектрах поглощения реакционной системь, три- и тетранитро замещенные Zn-октаэтилпорфирины могут рассматриваться в качестве молекулярных оптических устройств для распознавания мальх гетероциклических субстратов.

Ключевые слова: Zn-октаэтилпорфирин, мезо-нитрозамещенные порфирины, электроноакцепторные группы, аксиальная координация, связывающая способность, константа устойчивости. 


\section{Introduction}

Axial coordination in metalloporphyrins is a main driving force of processes of molecular recognition and self-organization of tetrapyrrolic macrocycles into supramolecular ensembles. According with the literature ${ }^{[1-4]}$ and our own experimental data ${ }^{[5-11]}$ it is mainly determined by a structure of porphyrin macrocycle, basicity of an extra-ligand and nature of a solvent. Among the listed factors a structure of tetrapyrrole macrocycles renders the highest influence on the metalloporphyrin's ability to additional coordination of a ligand, first of all, due to an electronic influence of the substituents. Besides, a chemical modification porphyrin structure can create steric hindrances for ligands axial coordination, or, on the contrary, form intramolecular cavities favorable for additional ligands binding. ${ }^{[1-15]}$ Stability constants of complexes between the correspondingly modified porphyrins and organic ligands of different nature, in comparison with porphyrins of relatively simple structures, can differ by several orders.

This work is devoted to UV-Vis studying of the influence of step-by-step meso-nitro substitution in $\mathrm{Zn}$ octaethylporphyrin on its binding ability towards imidazole (L1) and 1-methylimidazole (L2) in toluene.

\section{Experimental}

Zn-5-nitro-2,3,7,8,12,13,17,18-octaethylporphyrin (2), Zn5,15-dinitro-2,3,7,8,12,13,17,18-octaethylporphyrin (3), Zn5,10,15-trinitro-2,3,7,8,12,13,17,18-octaethylporphyrin (4) and Zn-5,10,15,20-tetranitro-2,3,7,8,12,13,17,18-octaethylporphyrin (5) were obtained according to the known procedures. ${ }^{[16,17]}$ 2,8,12,18-Tetrabutyl-3,7,13,17-tetramethylporphyrin (6), 5,15-diphenyl-2,8,12,18-tetrabutyl-3,7,13,17-tetramethylporphyrin (7) and 5,10,15,20-tetraphenyl-2,8,12,18-tetrabutyl-3,7,13,17-tetramethylporphyriyn (8) were obtained according to ${ }^{[18]}$. Zn2,3,7,8,12,13,17,18-octaethylporphyrin (1) was obtained by complexation of the corresponding porphyrin ligand $(2,3,7,8$, $12,13,17,18$-octaethylporphyrin) with zinc acetate in boiling dimethylformamide and showed the best correlation with the spectral data presented for this compound according to ${ }^{[19]}$. 2,3,7,8,12,13,17,18-Octaethylporphyrin, imidazole, 1-methylimidazole and toluene from Sigma-Aldrich were used without purification. UV-Vis spectra of the porphyrinates and their evolution upon addition of the ligands were measured on a Carry 100 spectrophotometer.

The UV-visible absorption spectral studies reveal red shifted Soret and visible bands upon addition of the ligands to a solution of the investigated porphyrins confirming that the $\mathrm{N}$-containing entity of the ligands binds to the $\mathrm{Zn}$-cation of the coordination centre of the tetrapyrrolic macrocycle.

The stability constant of the metalloporphyrin complexes with the ligands in ratio of $1: 1\left(K_{\text {assoc }}\right)$ according to the literature ${ }^{[7,8]}$ were calculated based on spectrophotometric data at two wavelengths (decreasing and increasing) using the following relationship:

$$
K_{\text {assoc. }}=\frac{[A-B]}{[A] \cdot[B]}=1 /[B]\left(\frac{\Delta A_{i, \lambda_{1}}}{\Delta A_{o, \lambda_{1}}} \cdot \frac{\Delta A_{o, \lambda_{2}}}{\Delta A_{i, \lambda_{2}}}\right) \cdot M^{-1},
$$

where, $\lambda_{1}$ is the decreasing wavelength, $\lambda_{2}$ is the increasing wavelength, $[A]$ is the Zn-porphyrin concentration, $[B]$ is the ligand concentration, $\Delta A_{0}$ is the maximal change of the optical density at the given wavelength, $\Delta A$ is the change of the optical density of the solution at a given wavelength at a given concentration.

\section{Results and Discussion}

Axial coordination of $\mathbf{L} \mathbf{1}$ and $\mathbf{L} \mathbf{2}$ on Zn-porphyrins (1-5) is accompanied by characteristic red shift of absorption bands in the UV-Vis spectra of the system porphyrinate-ligand. It should be noted that upon complexation of the porphyrinates with the monodentate ligands, over a wide concentration range of the ligands $\left(C_{\mathrm{L}}=0 \div 3 \cdot 10^{-4} \mathrm{M}\right)$, changes in the UVVis spectra of the reaction mixture occur with the formation of one family of spectral curves with one set of isosbestic points. The details of spectrophotometric titration upon investigation of the host-guest interactions are described in our previous works. ${ }^{[7-10]}$ The titration curve has one step, which indicates the formation of a single type of complexes in a ratio of 1:1. The changes in the UV-Vis spectra of the system 1-L1 and corresponding binding isotherms are depicted in Figures 1, 2 as an example.

It was found out that step-by-step meso-substitution of the tetrapyrrolic core by one (2), two (3), three (4) and four (5) nitro groups leads to the essential increasing of the stability constants of 1:1 complexes between the porphyrinates $\mathbf{2 - 5}$ and monodentate ligands $\mathbf{L} \mathbf{1}$ and $\mathbf{L 2}$ as compared with the similar complexes of porphyrinate $\mathbf{1}$ (Table 1, Figure 3).

Table 1. Stability constants of 1:1 complexes $\left(K_{\text {assoc }}, \mathrm{M}^{-1}\right)$ between porphyrinates 1-5 and monodentate ligands $\mathbf{L 1}, \mathbf{L 2}$ in toluene, $C_{\mathrm{ZnP}}=1.1 \cdot 10^{-5} \mathrm{M}$.

\begin{tabular}{ccc}
\hline № & L1 & L2 \\
\hline $\mathbf{1}$ & 25100 & 32800 \\
$\mathbf{2}$ & 41900 & 67200 \\
$\mathbf{3}$ & 88700 & 127000 \\
$\mathbf{4}$ & 188000 & 196700 \\
$\mathbf{5}$ & 294000 & 329000 \\
$\mathbf{6}$ & 25700 & - \\
$\mathbf{7}$ & 26200 & - \\
$\mathbf{8}$ & 26540 & - \\
\hline
\end{tabular}

The error in determining of the stability constants was $5-7 \%{ }^{[18]}$

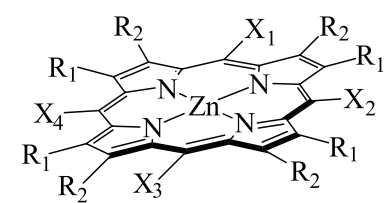

$\begin{array}{ll}\mathrm{X}_{1}=\mathrm{X}_{2}=\mathrm{X}_{3}=\mathrm{X}_{4}=\mathrm{H} ; & \mathrm{R}_{1}=\mathrm{R}_{2}=\mathrm{C}_{2} \mathrm{H}_{5} \\ \mathrm{X}_{1}=\mathrm{NO}_{2}, \mathrm{X}_{2}=\mathrm{X}_{3}=\mathrm{X}_{4}=\mathrm{H} ; & \mathrm{R}_{1}=\mathrm{R}_{2}=\mathrm{C}_{2} \mathrm{H}_{5} \\ \mathrm{X}_{1}=\mathrm{X}_{3}=\mathrm{NO}_{2}, \mathrm{X}_{2}=\mathrm{X}_{4}=\mathrm{H} ; & \mathrm{R}_{1}=\mathrm{R}_{2}=\mathrm{C}_{2} \mathrm{H}_{5} \\ \mathrm{X}_{1}=\mathrm{X}_{2}=\mathrm{X}_{3}=\mathrm{NO}_{2}, \mathrm{X}_{4}=\mathrm{H} ; \mathrm{R}_{1}=\mathrm{R}_{2}=\mathrm{C}_{2} \mathrm{H}_{5}\end{array}$

$$
\begin{array}{ll}
\mathrm{X}_{1}=\mathrm{X}_{2}=\mathrm{X}_{3}=\mathrm{X}_{4}=\mathrm{NO}_{2} ; & \mathrm{R}_{1}=\mathrm{R}_{2}=\mathrm{C}_{2} \mathrm{H}_{5} \\
\mathrm{X}_{1}=\mathrm{X}_{2}=\mathrm{X}_{3}=\mathrm{X}_{4}=\mathrm{H} ; & \mathrm{R}_{1}=\mathrm{C}_{4} \mathrm{H}_{9}, \mathrm{R}_{2}=\mathrm{CH}_{3} \\
\mathrm{X}_{1}=\mathrm{X}_{3}=\mathrm{C}_{6} \mathrm{H}_{5}, \mathrm{X}_{2}=\mathrm{X}_{4}=\mathrm{H} ; & \mathrm{R}_{1}=\mathrm{C}_{4} \mathrm{H}_{9}, \mathrm{R}_{2}=\mathrm{CH}_{3} \\
\mathrm{X}_{1}=\mathrm{X}_{2}=\mathrm{X}_{3}=\mathrm{X}_{4}=\mathrm{C}_{6} \mathrm{H}_{5} ; & \mathrm{R}_{1}=\mathrm{C}_{4} \mathrm{H}_{9}, \mathrm{R}_{2}=\mathrm{CH}_{3}
\end{array}
$$




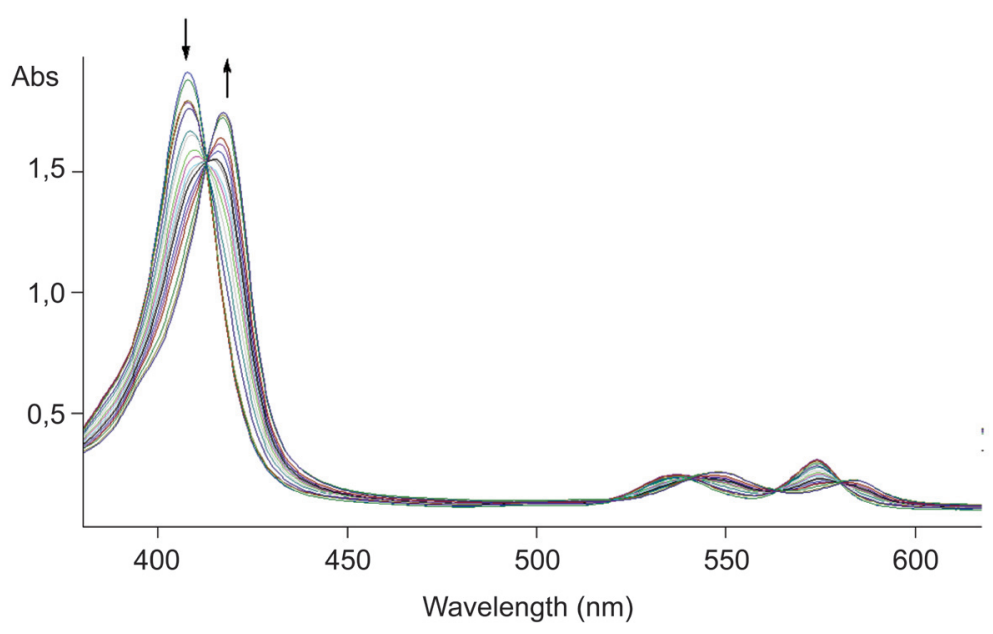

Figure 1. Changes in the UV-Vis spectra of the system 1-L1 in toluene at $20^{\circ} \mathrm{C}, C_{1}=1.0 \cdot 10^{-5} \mathrm{M}$.

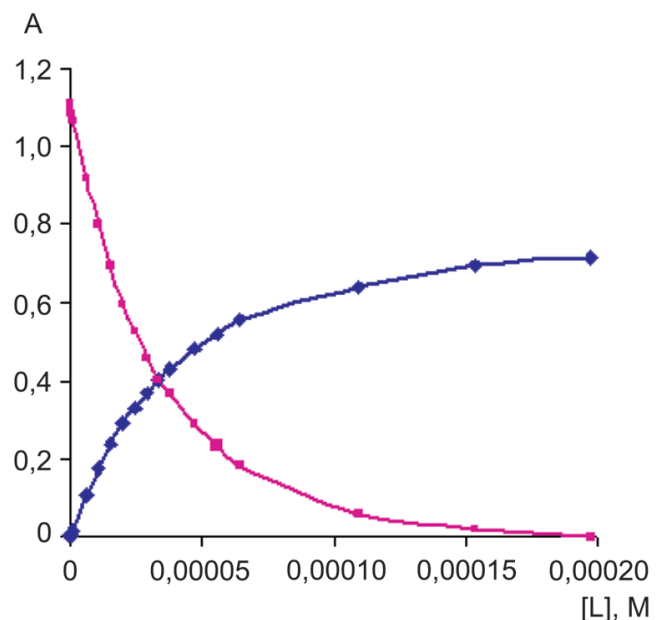

Figure 2. Binding isotherms of the system 1-L1 on the decreasing $(400 \mathrm{~nm})$ and the increasing $(426 \mathrm{~nm})$ waves lengths in toluene at $20^{\circ} \mathrm{C}, C_{1}=1.0 \cdot 10^{-5} \mathrm{M}$.

It should be noted that meso-nitro substitution could have strong influence on a porphyrin $\pi$-electronic system both due to an electronic effect of the substituents, and deformation of the tetrapyrrolic macrocycle. Step-by-step introduction into the Zn-octaethylporphyrin of one, two, three and four nitro-groups has accompanied by essential distortion of the porphyrinate molecule. Red shift of absorption bands in UVVis spectra in going from $\mathbf{1}$ to $\mathbf{2 - 5}$ testifies in favor of this assumption (Table 2).

Similar dependence is known in the case of step-bystep meso-phenyl substitution in a porphyrin macrocycle. [5] However, unlike meso-phenyl substitution of Zn-octaalkylporphyrins [in going from 2,8,12,18-tetrabutyl3,7,13,17-tetramethylporphyrin (6) to 5,15-diphenyl-2,8, 12,18-tetrabutyl-3,7,13,17-tetramethylporphyrin (7) and 5,10,15,20-tetraphenyl-2,8,12,18-tetrabutyl-3,7,13,17-tetramethylporphyrin $(\mathbf{8})$ ] in the case of meso-nitro substituted $\mathrm{Zn}$ porphyrinates 2-5 the chemical modification is accompanied

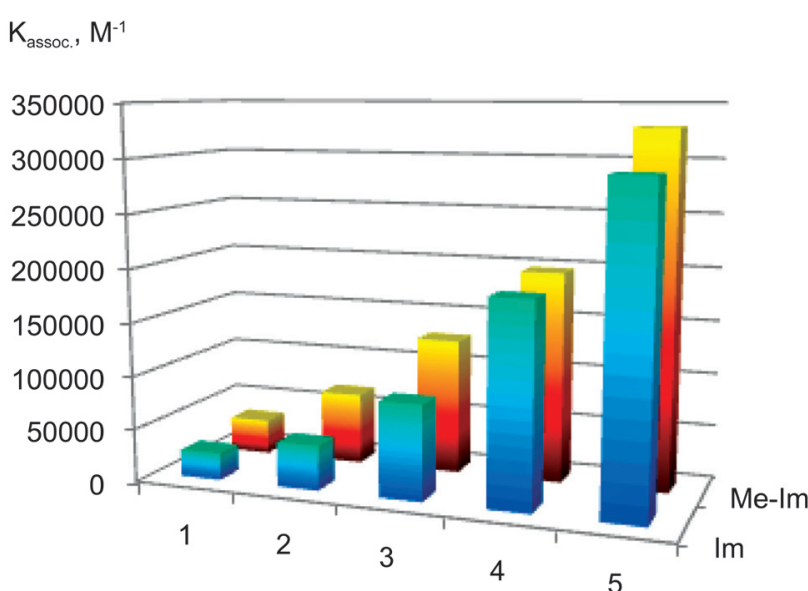

Figure 3. Dependence of the stability constants of porphyrinates 1-5 with the ligands $\mathbf{L} \mathbf{1}$ and $\mathbf{L} 2$ on the nature of small $\mathrm{N}$-containing organic molecules in toluene, $25^{\circ} \mathrm{C}$.

by essential increasing in binding ability of the porphyrinates towards the ligands $\mathbf{L} 1$ and L2 (Table 1).

Table 2. Position of the bands in UV-Vis spectra of Zn-porphyrins 1-5 in dichloromethane. ${ }^{[16,17]}$

\begin{tabular}{|c|c|c|c|c|c|c|}
\hline № & \multicolumn{6}{|c|}{$\lambda, \mathrm{nm}$} \\
\hline 1 & & 331 & 402 & 490 & 532 & 569 \\
\hline 2 & & 350 & 401 & 497 & 534 & 573 \\
\hline 3 & & 352 & 404 & 503 & 539 & 576 \\
\hline 4 & 264 & 360 & 413 & 510 & 547 & 571 \\
\hline 5 & 260 & 370 & 426 & 520 & 561 & 580 \\
\hline
\end{tabular}

Probably, the nitro-groups, except macrocycle deformation, have strong electronic influence on $\pi$-electronic system of tetrapyrrolic macrocycle. It is known that the higher is an electronic density of delocalized $\pi$-electronic 
system of porphyrin macrocycle, the stronger are the N-Zn bonds of porphyrinate coordination center, and, as a result, donor-acceptor interactions between porphyrinate zinc cation and nitrogen atom of a ligand $(\mathrm{Zn}-\mathbf{L})$ is weaker. ${ }^{[1]}$ The acceptor nitro-groups, decreasing an electronic density of the $\pi$-electronic system, simultaneously increase a partial positive charge on the porphyrinate zinc cation and facilitate $\mathrm{Zn}-\mathbf{L}$ interactions. The more nitro-groups are in a macrocycle, the higher is a corresponding binding constant (Table 1).

\section{Conclusions}

Thus, the influence of step-by-step meso-nitro substitution in Zn-octaethylporphyrin on its binding ability towards imidazole and 1-methylimidazole was investigated by the method of UV-Vis titration in toluene. The stability constants of the resulting complexes and concentration intervals of their existence were determined. Taking into account the fact that binding is accompanied by a clear and easily identifiable response in the UV-Vis spectra of the reaction mixture, tri- and tetranitro substituted Zn-porphyrins could be considered as molecular optical sensing devices for small heterocyclic substrates.

Acknowledgements. We are indebt for financial support to the Russian Foundation for Basic Research (Project №№ 1403-00011_a, 14-03-00009) and Program of the Presidium of RAS №24 «Nanomedicines and their targeted delivery».

\section{References}

1. Berezin B.D, Koifman O.I. Russ. Chem. Rev. 1980, 49, 11881213 [Uspekhi Khimii 1980, 49, 2389-2415 (in Russ.)].

2. Ogoshi H., Mizutani T., Hayashi T., Kuroda Y. Porphyrins and Metalloporphyrins as Receptor Models in Recognition. In: The Porphyrin Handbook, Vol. 6 (Kadish K.M., Smith K.M., Guilard R., Eds.) New York: Academic Press, 2000, 280-340.
3. Wojaczyński J., Latos-Grazhynski L. Coord. Chem. Rev. 2000 , 204, 113-170.

4. Imamura T., Fukushima K. Coord. Chem. Rev. 2000, 198, 133156.

5. Mamardashvili N.Zh., Golubchikov O.A. Russ. Chem. Rev. 2001, 70, 577-606 [Uspekhi Khimii 2001, 70, 656-686 (in Russ.)].

6. Mamardashvili G.M., Kulikova O.M. Russ. J. Coord. Chem. 2006, 32, 756-760 [Koord. Khim. 2006, 32, 786-790 (in Russ.)].

7. Mamardashvili G.M., Mamardashvili N.Zh., Koifman O.I. Russ. J. Inorg. Chem. 2007, 52, 1215-1219 [Zh. Neorg. Khim. 2007, 52, 1299-1303 (in Russ.)].

8. Mamardashvili G.M., Kulikova O.M., Mamardashvili N.Zh., Koifman O.I. Russ. J. Coord. Chem. 2008, 34, 427-433 [Koord. Khim. 2008, 34, 435-441 (in Russ.)].

9. Mamardashvili G.M., Kulikova O.M., Koifman O.I. Russ. J. Gen. Chem. 2008, 78, 1964-1971 [Zh. Obchsh. Khim. 2008, 78, 1728-1735 (in Russ.)].

10. Mamardashvili G.M., Kulikova O.M., Mamardashvili N.Zh., Koifman O.I. Russ. J. Gen. Chem. 2007, 77, 1965-1971 [Zh. Obchsh. Khim. 2007, 77, 1915-1922 (in Russ.)].

11. Puchovskaya S.G., Guseva L.Zh., Kuvshinova E.M., Mamardashvili N.Zh., Golubchikov O.A. Koord. Khim. 1998, 24, 851-856 (in Russ.).

12. Bonar-Law R.P., Sanders J.K.M. Chem. Soc., Perkin Trans. 1 1995, 3085-3096.

13. Hunter C.A., Meah M.N., Sanders J.K.M. J. Am. Chem. Soc. 1990, 112, 5773-5780.

14. Froidevaux J., Ochsenbein P., Bonin M., Scheck K., Maltese P., Gisselbrecht J-P, Weiss J. J. Am. Chem. Soc. 1997, 119, 12362-12363.

15. Nguyen N.T., Mamardashvili G., Gruzdev M., Mamardashvili N., Dehaen W. Supramol. Chem. 2013, 25, 180-188.

16. Gong L., Dolphin D. Can. J. Chem. 1985, 63, 401-401.

17. Watanabe E., Nishimura S., Ogoshi H., Yoshida Z. Tetrahedron $\mathbf{1 9 7 5}, 31,1385-1390$.

18. Mamardashvili N.Zh., Golubchikov O.A. Russ. Chem. Rev. 2000, 69, 307-323 [Uspekhi Khimii 2000, 69, 337-354].

19. Mamardashvili N.Zh. In: Proceedings of the IX International Youth School "Chemistry of Porphyrins and Related Compounds», Ivanovo (Russia), 2012, p. 17. 